\title{
Aesthetics-based classification of geological structures in outcrops for geotourism purposes: a tentative proposal
}

\author{
Anna V. Mikhailenko ${ }^{1}$, Olesya V. Nazarenko ${ }^{1}$, \\ Dmitry A. Ruban ${ }^{2,3 *} \&$ Pavel P. Zayats ${ }^{4}$ \\ ${ }^{1}$ Department of Physical Geography, Ecology and Nature Protection, Institute of Earth Sciences, Southern Federal \\ University, Zorge Street 40, Rostov-na-Donu, 344090 Russia \\ ${ }^{2}$ Department of Tourism, Higher School of Business, Southern Federal University, 23-ja linija Street 43, Rostov-na- \\ Donu, 344019 Russia \\ ${ }^{3}$ postal address: P.O. Box 7333, Rostov-na-Donu, 344056 Russia; e-mail: ruban-d@mail.ru \\ ${ }^{4}$ Camp for Practice and Educational Tourism ‘Belaja Retchka', Southern Federal University, Nikel' (Dakhovskaja Post \\ Office), Majkop District, Republic of Adygeja, 385792 Russia \\ ${ }^{*}$ corresponding author
}

\begin{abstract}
The current growth in geotourism requires an urgent development of classifications of geological features on the basis of criteria that are relevant to tourist perceptions. It appears that structure-related patterns are especially attractive for geotourists. Consideration of the main criteria by which tourists judge beauty and observations made in the geodiversity hotspot of the Western Caucasus allow us to propose a tentative aesthetics-based classification of geological structures in outcrops, with two classes and four subclasses. It is possible to distinguish between regular and quasi-regular patterns (i.e., striped and lined and contorted patterns) and irregular and complex patterns (paysage and sculptured patterns). Typical examples of each case are found both in the study area and on a global scale. The application of the proposed classification permits to emphasise features of interest to a broad range of tourists. Aesthetics-based (i.e., non-geological) classifications are necessary to take into account visions and attitudes of visitors.
\end{abstract}

Keywords: geological heritage, stratification, fault, fold, epikarst, Western Caucasus, Russia

\section{Introduction}

Geotourism is a globally growing activity, the essence of which is linked to people's curiosity about unique and/or peculiar geological and geomorphological phenomena (Hose, 2000, 2012; Dowling, 2011; Ruban, 2015). The latter are accessible at geoheritage sites (geosites), inclusive of geoparks, as well as in museums. Potential geotourists include professionals and students of the earth sciences, but also amateurs and casual visitors (see Dowling,
2011 for a tentative classification). It appears that the more geotourism grows, the greater becomes the number of the latter. As a result, adequate explanation (interpretation) of geological features are increasingly more urgently needed (e.g., Bruno et al., 2014). A similarly important or even larger problem also exists, namely visual attraction on the part of geotourists to objects of heritage.

In fact, often the interest of visitors in geological features is not based on any "purely" geological fact, but aesthetic properties matter. These in- 
clude, first of all, physical size, colour and pattern. The last-named feature is particularly important because geological features rarely boast gigantism or bright colours. Too often tourists note just "grey rocks" that are not worthy of note. However, various patterns are often visible in outcrops because of layering, folding, faulting, etc. In the other words, patterns reflect geological structures. The aim of the present note is to propose a tentative, aesthetics-based classification of geological structures in natural and artificial outcrops that can be used in geotourism for evaluation of geosite attractiveness.

\section{Conceptual premises}

Geological structures (sensu lato) result from magmatic, sedimentary, metamorphic, tectonic and other processes that create visible heterogeneity in rocks and rock assemblages. Sedimentary and tectonic structures are common; other phenomena include thermal jointing in basalts, karst fissures, etc. Geological classifications of such are well known and widely accepted. Sedimentary structures are linked to bedding surfaces and internal features, diagenetic changes of rocks, fossil content, bioturbation, etc. Speaking more generally these are also related to layering (stratification) and geometry of sedimentary bodies (e.g., Tucker, 2011). Tectonic structures are produced by deformation that rocks experienced under compression, extension or strikeslip motions. The most obvious examples are folds, faults, joints, etc. Morphological and genetic classifications are used to distinguish different structures (e.g., Peacock et al., 2016), but how well do such classifications serve the purposes of geotourism? Of course, professional field descriptions of structures related to geological heritage should be based on standard principles and employ standard terminology. It is not surprising that available typologies of items of geological heritage are based on "purely" geological criteria (e.g., Ruban, 2010; Bradbury, 2014). However, the recognition of parallel layering or isoclinal folds does not tell anything about the importance of a given geosite to tourists, especially to casual visitors. The invention of an aesthetics-based classification, essentially non-geological, will permit to facilitate a proper selection of geosites depending on their visual perception by tourists. Although aesthetics is only one of many factors of attractiveness of geological localities, it seems to be the main for occasional visitors, who cannot judge these localities on the basis of geological knowledge.

Geosite assessment (both qualitative and quantitative) is a challenging procedure, despite the fact that appropriate and well-developed approaches for this procedure do exist (Brilha, 2016). The importance of aesthetic properties of geological objects in geoconservation and geotourism has been known for many years (Tourtellot, 2006; El Wartiti et al., 2008; Boley et al., 2011; Fassoulas et al., 2012; Ghazi \& Ghadiri, 2012; Gray, 2013; Phuong et al., 2013; Unjah et al., 2013; Walliss \& Kok, 2014; Necheş \& Erdeli, 2015; Coratza et al., 2016; Hose, 2016; Jorgenson \& Nickerson, 2016; Warowna et al., 2016; Habibi \& Ruban, 2017). However, it is uncommon to evaluate such properties on a quantitative or semi-quantitative basis. One interesting approach that deserves closer attention was implemented by Warowna et al. (2016), who judged the degree of aesthetic attractiveness counting the number of colours represented at geosites. If, as noted above, colour is only one of many aesthetic properties, an alternation of colours may reveal nothing less than the pattern relevant to what can be referred to as "structure" (e.g., stratification). As has been determined in studies of waterfalls (Plumb, 1993; Hudson, 2002), the physical properties of natural objects can be employed for qualitative and quantitative assessment of their aesthetic attractiveness and tourism potential, although such criteria are not always easy to interpret. Two main problems in aesthetic judgements of geosites are as follows. First, the very understanding of what is aesthetic differs between specialists. Second, this understanding differs and sometimes ignores the preferences of geosite visitors, i.e., geotourists. Previous research into tourism demonstrates that the vision of tourist attractions may be different and depend on various factors (e.g., Kirillova et al., 2014; van der Jagt et al., 2014).

The limited geological knowledge of casual visitors facilitates judgement of geological heritage in the usual aesthetic frame. If so, tourists are likely to pay greater attention to outcrops at which patterns are visible and these patterns match the stereotypic vision of beauty. The only professional earth scientists may judge outcrops aesthetically attractive because of their genuine geological value. In other words, visitors of geosites and geoparks see, first of all, more or less beautiful patterns but not structures. In such a case, the development of an aesthetics-based classification of geological structures in outcrops for geotourism purposes should be aimed at patterns, the beauty of which may be valued irrespective of geological considerations. Pattern is potentially the most important aesthetic property in geotourism. First, structure-related patterns are common in outcrops. Second, a pattern is something that can be judged without any specific knowledge. Third, geological patterns are 
something unexpected and exciting because pattern is usually understood by people as something artificial, specially created for admiration. Seeing patterns in natural rocks impresses visitors because of they can imagine the natural forces that created something that also mankind could have produced.

Recently, Kirillova et al. (2014) have summarised the main criteria by which tourists judge beauty. Evidently, these are the aesthetic properties of sites, which include scale, presence/absence of people, time, condition, sound, balance, diversity, novelty, shape and uniqueness. Two of these properties are directly linked to what is called "pattern". These are shape (angularity, complexity and symmetry, sensu Kirillova et al., 2014) and balance (suitability of visual cues to setting, perceived integrity and flow of visual cues, sensu Kirillova et al., 2014). Geological structures may create patterns with elements of different shape (see examples below). As far as balance is concerned, geological patterns seem to be unnatural, as explained above. Of course, different people can judge the properties of each given site differently, i.e., on the basis of their own mental attitudes. However, the study by Kirillova et al. (2014) ensures that tourists pay attention to the properties noted, and this is the most important. If patterns related to geological structures are linked directly to the two above-mentioned properties, this means that the presence of these patterns in outcrops makes the latter objects of aesthetic judgements, i.e., objects of interest.

\section{Classification and examples}

An aesthetics-based classification of geological structures in outcrops should be based on the view of patterns produced by these structures and perceived by visitors. Criteria and subcriteria specified by Kirillova et al. (2014) can be helpful. Moreover, the tentative classification presented here is based on the authors' field experience in the geodiversity hotspot of the Western Caucasus (southwest Russia) (Fig. 1). This area boasts a particularly rich geological heritage and possesses numerous spectacular outcrops, many of which are located along roads and tourist routes (Ruban, 2010; Lubova et al., 2013; Gnezdilova et al., 2015; Moroni et al., 2015; Plyusnina et al., 2015). It represents a wide spectrum of geological phenomena, many of which are related to the Mesozoic development of semi-restricted marginal seas of the Neo-Tethys Ocean, where thick siliciclastic and carbonate deposits accumulated. The study area also experienced a series of deformational phases, of which the Hercynian (late

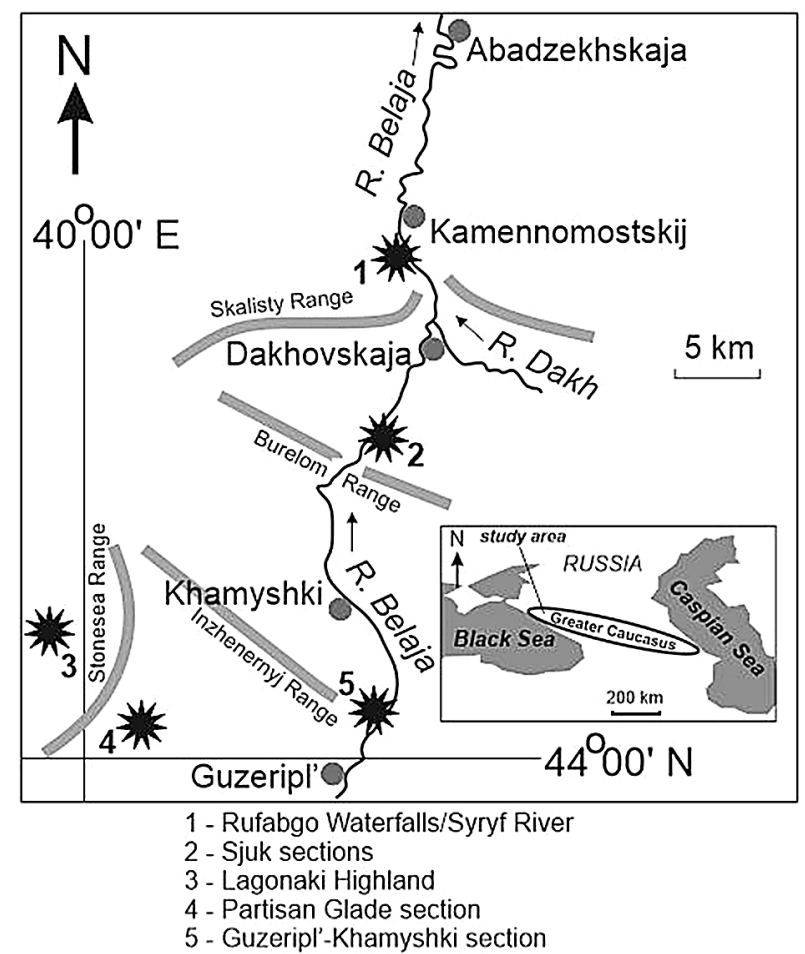

Fig. 1. Geographical location of the study area.

Palaeozoic) and Alpine orogenies (late Cenozoic) were the strongest.

It is here suggested to divide geological structures visible in outcrops into two classes and four subclasses depending on the general view of patterns.

Class 1. Regular and quasi-regular patterns. This class encompasses geological structures with more or less regular shapes. These are characterised by a high degree of angularity, a high degree of symmetry and a varying degree (chiefly low to moderate) of complexity. The aesthetic value of these patterns is created by their shapes that resemble some artificial ornaments.

Subclass 1.1. Striped and lined patterns. Most commonly, such patterns are produced by sedimentary rock stratification, especially when layers of different colour intercalate. Moreover, the inclined or vertical position of layers makes patterns more impressive. Typical examples are found in the Western Caucasus, where parallel and more or less inclined layers of Permian, Triassic and Jurassic sedimentary rocks can be seen in numerous outcrops (Fig. 2). Outcrops representing single faults should be also assigned to this subclass, because these faults will be perceived as lines crossing the rock massif. Stripes and lines appear to be essentially the same from an aesthetic point of view, although their true geological nature may of course be very different. 

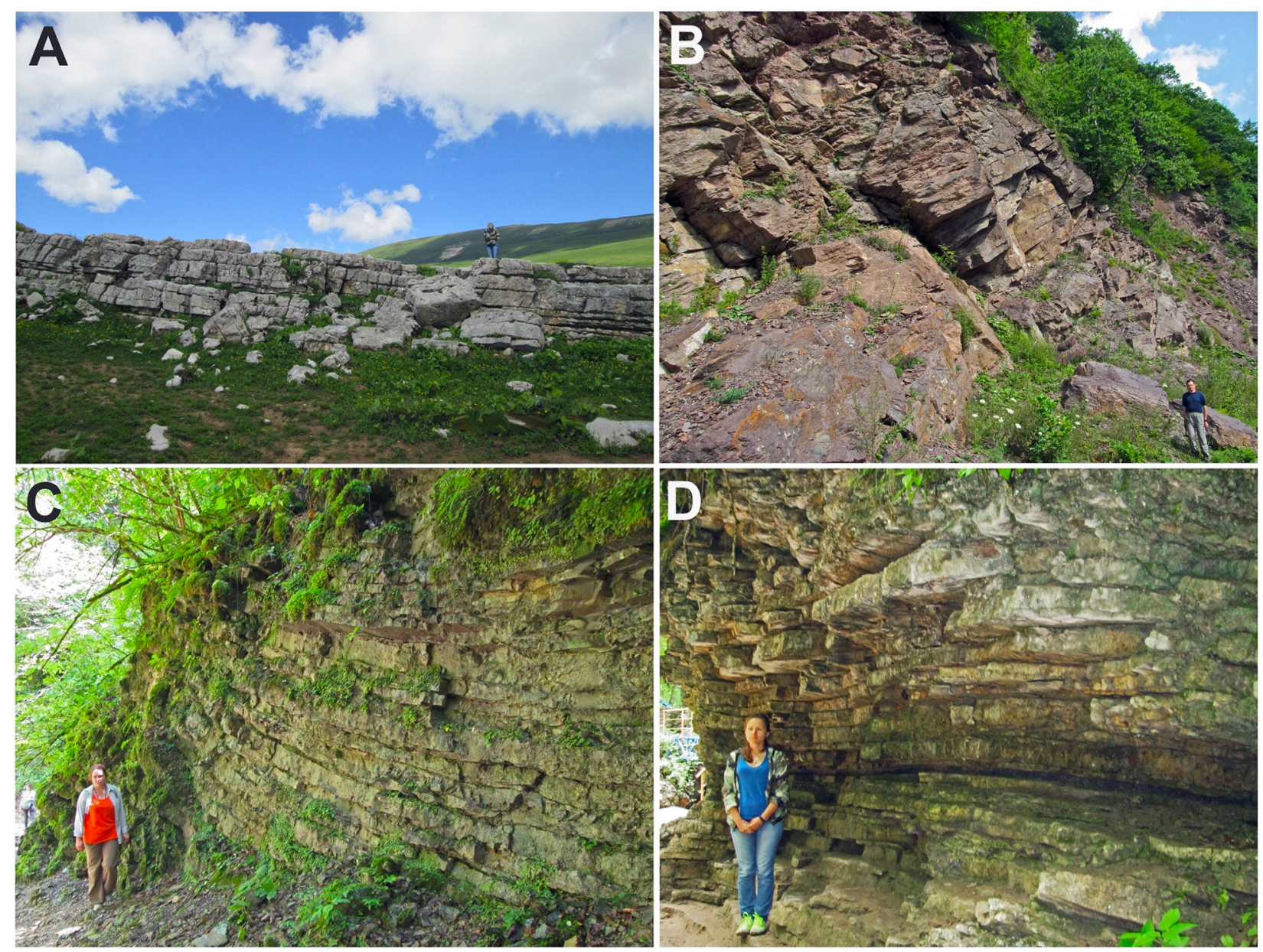

Fig. 2. Striped and lined pattern: A - Upper Jurassic limestones (Lagonaki Highland) (A.V.M. for scale); B - Lower-?Middle Permian siliciclastics (Guzeripl'-Khamyshki section) (D.A.R. for scale); C, D - Triassic limestones (Rufabgo Waterfalls/Syryf River) (O.V.N. on C and A.V.M. on D for scale). For location of outcrops see Fig. 1.

Subclass 1.2. Contorted patterns. Such patterns are produced chiefly by folding, especially when folds are relatively small in size and fully visible in outcrops. Typical examples in the Western Caucasus can be found in those places where intensively folded Triassic and Jurassic deposits outcrop (Fig. $3)$. It should be added that the aesthetic value of the Triassic chevron folds in the study area was recognised by Gaetani et al. (2005), who linked these folds to Cimmerian deformation events; the view of these folds is so impressive that their image was put on the cover of the journal issue in which the paper was published. As far as Jurassic folds in the Western Caucasus are concerned, some of these are linked to submarine slumping on the continental slope of the ancient sea basin or near-fault deformation during Alpine times.

Class 2. Irregular and complex patterns. This class includes geological structures with unusual shapes. The degree of angularity and symmetry may be different (usually low), but the degree of complexity is high. The aesthetic value of these patterns is created by their shapes that resemble impressionist or abstract painting or sculptures.

Subclass 2.1. Paysage patterns. These patterns look like large-scale handmade drawings in rocks. Different processes can lead to the development of structures that exhibit such patterns, but, these are mostly folding, faulting and weathering. A typical example can be found in the Western Caucasus where outcrops of the so-called "paysage flysch" occur along the Partisan Glade road (Fig. 4). The unusual pattern with rounded, wavy and other peculiar shapes occurs there as a result of a combination of intense folding, jointing and weathering (spheroidal weathering according to A.J. van Loon, pers. comm., 2015) of fine siliciclastics accumulated in the deep Early-Middle Jurassic sea.

Subclass 2.2. Sculptured patterns. Such patterns are often linked to structures formed by weathering and karstification along joints, tectonic fracture networks (see revised nomenclature in 


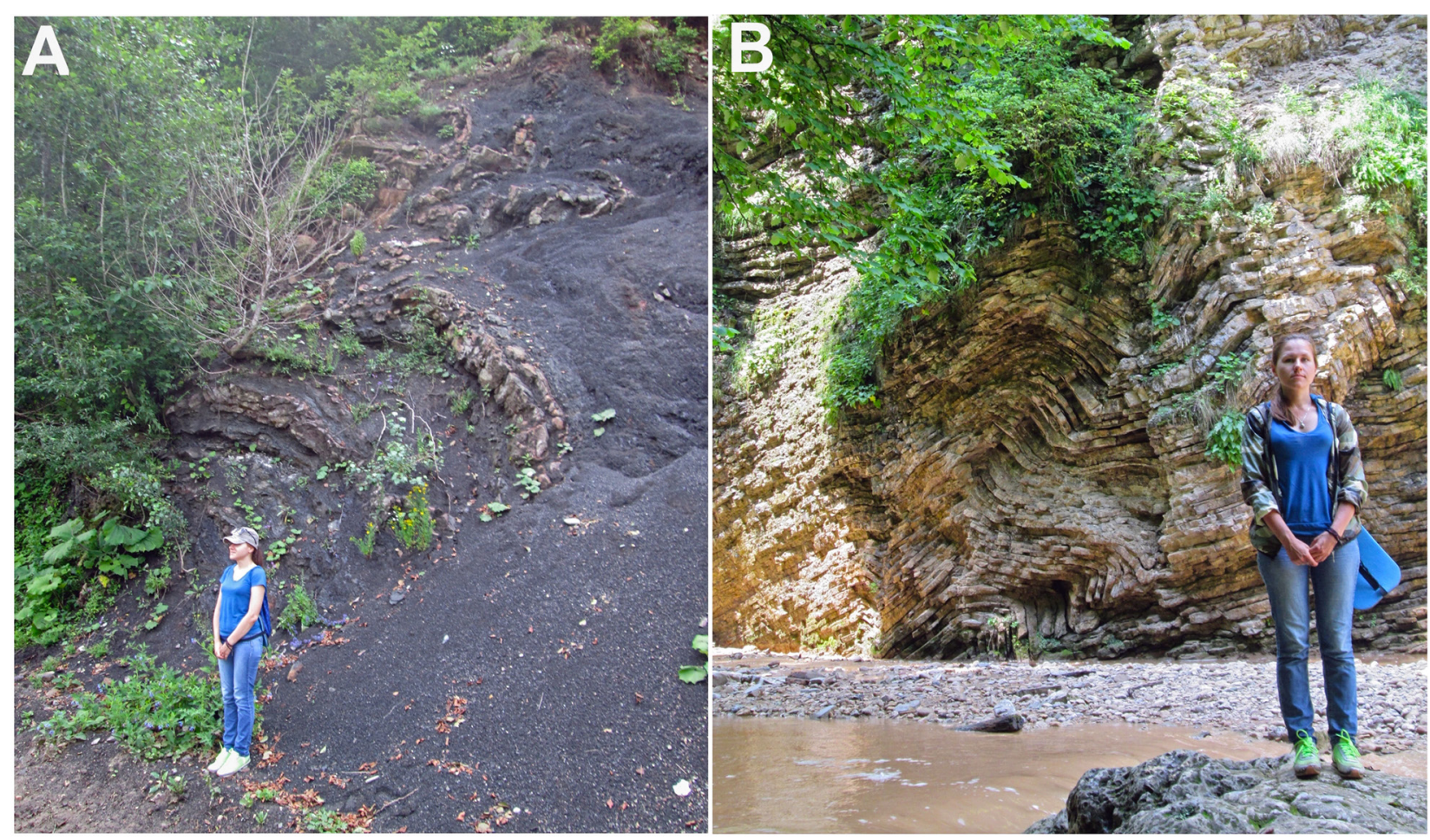

Fig. 3. Contorted pattern: A - folded Middle Jurassic shales with encrinite layers (Sjuk sections) (A.V.M. for scale); B folded and faulted Middle Triassic limestones (Rufabgo Waterfalls/Syryf River) (A.V.M. for scale). For location of outcrops see Fig. 1.

Peacock et al., 2016), thermal jointing in basalts, etc. Typical examples are found in the Lagonaki Highland of the Western Caucasus, where intense karstification on the surface of Jurassic limestones has created "cubes", irregular bodies and even "advanced" sculptures (small epikarst forms are repre-
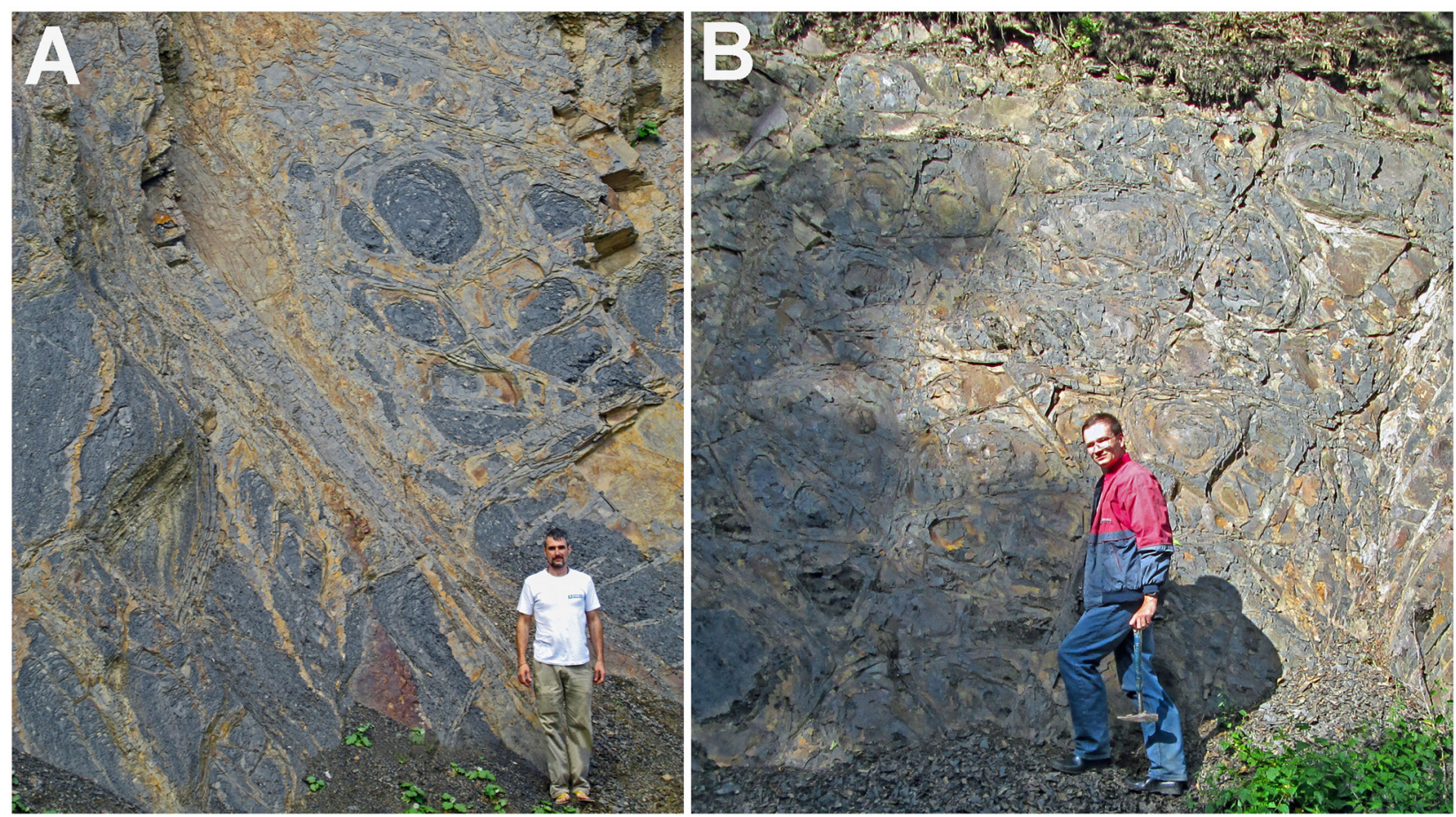

Fig. 4. Paysage pattern: A, B - strongly deformed and weathered Lower-Middle Jurassic shales (Partisan Glade section) (P.P.Z. in A and D.A.R. in B for scale). For location of outcrops see Fig. 1. 

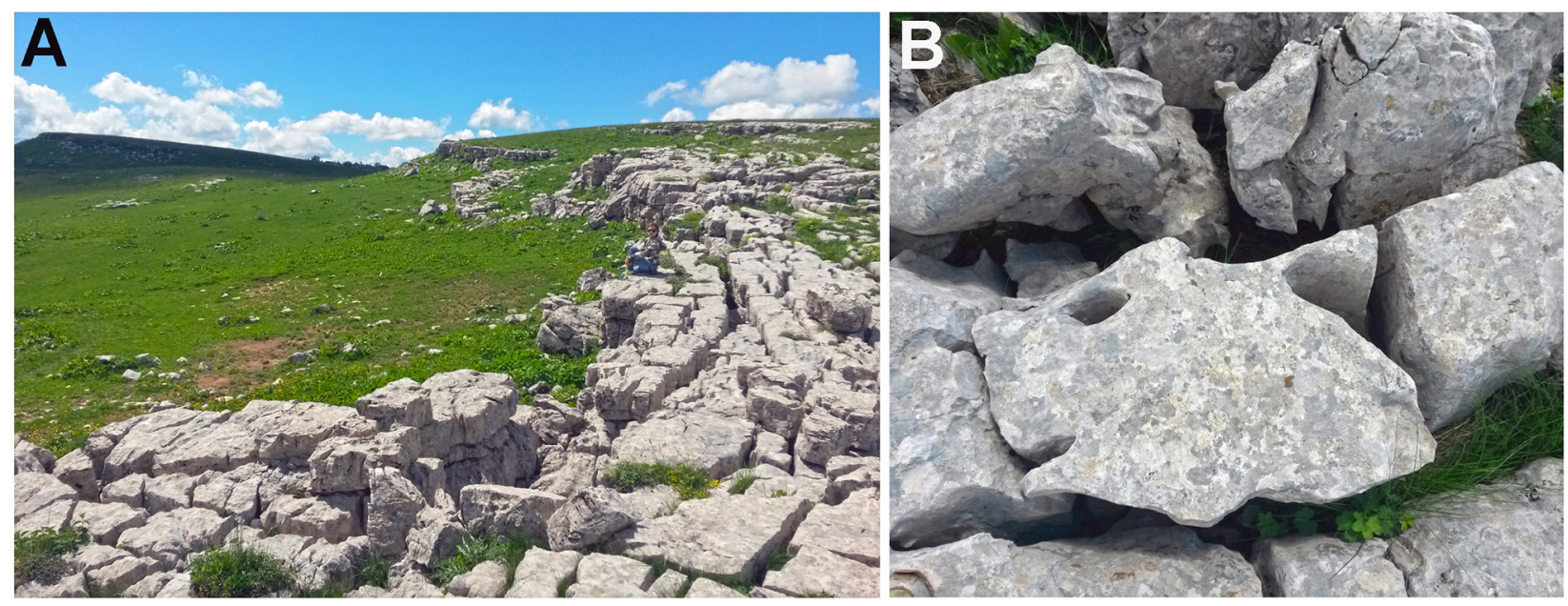

Fig. 5. Sculptured pattern: A - karren (grikes) developed along joints on the exposed surface of the Upper Jurassic limestones (Lagonaki Highland) (A.V.M. for scale); B - "cat's head" sculptured by superficial karstification at the same locality. For location of outcrops see Fig. 1.

sented here by kamenitzas, grikes, rilllenkarren and rinnenkarren) (Fig. 5). Processes of this kind were described comprehensively by Ginés et al. (2009; see Veress et al., 2013, 2014; Veress, 2016 for additional references). These geomorphological features are manifestations of structures controlled by joints and layering in the rocks. Known occurrences of columnar basalts (Kantha, 1981; Weaire \& O'Carroll, 1983; Wang et al., 2005; Goehring \& Morris, 2008; Hofmann et al., 2015) belong to this subclass, because of sculpture-like view of these columns and their groups.

Of course, geological structures may combine in extended sections and even within single outcrops. This occurs in the Rufabgo Waterfalls/Syryf River geosite, where both subparallel layering and chevron folds co-exist in the walls of the deep canyon. It is also expected that tourists will be more impressed by some patterns than by others, but the relevant preferences may vary between social groups and, thus, require special studies in the future.

The tentative classification proposed above can be applied broadly. For instance, a lengthy gallery of spectacular mid-Palaeozoic sections from across the globe is presented in the book published presently by Suttner et al. (2016). Each of them is an important geosite worthy of geotourism activities and the structures exhibited in these sections can be classified according to the scheme proposed in the present paper. The parallel layering of Devonian rocks at the Seneca Stone Quarry (USA) is an example of subclass 1.1, the folded Carboniferous deep-marine deposits in the Kugarchi section (Russia) are an example of subclass 1.2, the Devonian pillow lava (with "spotted" pattern) in the Lahn-Dill area (Germany) is an example of subclass
2.1, while the karstified surface of the Carboniferous-Permian Akiyoshi reefal limestones (Japan) illustrates subclass 2.2. The classification can also be applied to the geological heritage of some geoparks such as the Jeju Island Geopark in South Korea described by Woo et al. (2013) and the Hong Kong Global Geopark in China characterised by Wang et al. (2015), which both boast excellent representation of geological structures. The most impressive feature of the Penghu Geopark in Taiwan is the colossal reversed flower/mushroom-like outcrop of columnar basalts (Wang et al., 2005). This object can be assigned to subclass 2.2 on account of its general view as a kind of sculpture.

\section{Discussion and conclusion}

The simple aesthetics-based classification of geological structures in outcrops proposed in the present paper should serve the practical purposes of geotourism, namely to help evaluate the attractiveness of geosites. To catch the attention of potential geotourists, outcrops with spectacular patterns should be promoted properly by guides, brochures, special signs, on-line resources, etc. Such a classification will facilitate the choice of objects suitable for such a promotion, and it will also indicate on features that should be promoted. In this way, the approach "aesthetics first, geology second" may work well in support of the necessary tourist flows to geosites and geoparks.

Of course, aesthetic impressions should not replace professional geological explanations. The proposed classification may be seriously criticised by those specialists in geoconservation and geo- 
tourism who advocate a "purely" geological vision. Years have been spent in order to have geotourism develop from something too local and too specific to a global-scale activity. However, if geotourism has become part of tourism and hospitality industry (see also discussion in Jorgenson \& Nickerson, 2016), this means that the interests and attitudes of tourists cannot be ignored. Preferences and aesthetic stereotypes like those revealed by Kirillova et al. (2014) should be taken into account as seriously as possible. Without this, geotourism will be restricted to professionals and students, and the relevant activities will not satisfy casual visitors. This is why an aesthetics-based classification of geological structures is not a step back from modern science to primitive and intuitive descriptions, but a very necessary tool that will permit to popularise geological knowledge. It should be added that the same principle has been already applied to waterfalls by Haghe (2011) and Hudson (2013), and no controversy between the earth sciences and aesthetic impressions has been found.

This brief paper offers a very tentative classification that can be modified and extended further. The most promising direction for additional studies is linked to psychological experiments at geosites and in geoparks. Such research is conducted very actively in other fields of tourism (e.g., van der Jagt et al., 2014) and geotourism should not be excluded. Experiments of this kind should demonstrate how different geotourists see rocks, by which criteria they judge them, what they consider beautiful, etc. Of special interest is to find an answer to the question of how professional knowledge in geology changes aesthetic judgements of outcrops.

\section{Acknowledgements}

The authors thank the journal editors and both reviewers for their valuable suggestions and critical consideration of this work, D.E. Bruno (Italy), I.-M. Necheş (Romania), W. Riegraf (Germany), A.J. van Loon (Spain), $M$. Veress (Hungary), and many other colleagues for discussions and/or literature support. This research was partly funded by the SFU (Russia) (grant VnGr-07/201724 to A.V.M.).

\section{References}

Boley, B.B., Nickerson, N.P. \& Bosak, K., 2011. Measuring Geotourism: Developing and Testing the Geotraveler Tendency Scale (GTS). Journal of Travel Research 50, 567-578.

Bradbury, J., 2014. A keyed classification of natural geodiversity for land management and nature conservation purposes. Proceedings of the Geologists' Association 125, 329-349.

Brilha, J., 2016. Inventory and quantitative assessment of geosites and geodiversity sites: a review. Geoheritage 8, 119-134.

Bruno, D.E., Crowley, B.E., Gutak, Ja.M., Moroni, A., Nazarenko, O.V., Oheim, K.B., Ruban, D.A., Tiess, G. \& Zorina, S.O., 2014. Paleogeography as geological heritage: Developing geosite classification. Earth-Science Reviews 138, 300-312.

Coratza, P., Gauci, R., Schembri, J., Soldati, M. \& Tonelli, C., 2016. Bridging natural and cultural values of sites with outstanding scenery: evidence from Gozo, Maltese Islands. Geoheritage 8, 91-103.

Dowling, R., 2011. Geotourism's global growth. Geoheritage 3, 1-13.

El Wartiti, M., Malaki, A., Zahraoui, M., El Ghannouchi, A. \& Di Gregorio, F., 2008. Geosites inventory of the northwestern Tabular Middle Atlas of Morocco. Environmental Geology 55, 415-422.

Fassoulas, C., Mouriki, D., Dimitriou-Nikolakis, P. \& Iliopoulos, G., 2012. Quantitative assessment of geotopes as an effective tool for geoheritage management. Geoheritage 4, 177-193.

Gaetani, M., Garzanti, E., Polino, R., Kiricko, Yu., Korsakhov, S., Cirilli, S., Nicora, A., Rettori, R., Larghi, C. \& Bucefalo Palliani, R., 2005. Stratigraphic evidence for Cimmerian events in NW Caucasus (Russia). Bulletin de la Société géologique de France 176, 283-299.

Ghazi, I. \& Ghadiri, N., 2012. Assessing geotourism capabilities of Kavir National Park by applying the "Freeman" management strategy model. Journal of Environmental Studies 37, 65-78.

Ginés, A., Knez, M., Slabe, T. \& Dreybrodt, W. (Eds), 2009. Karst rock features: Karren scuplturing. Ljubljana (Karst Research Institute ZRC SAZU), 561 pp.

Gnezdilova, V.V., Ruban, D.A., Bruno, D.E., Perrotta, P., Crowley, B.E., Oheim, K.B. \& Zayats, P.P., 2015. Geoheritage sites with palaeogeographical value: some geotourism perspectives with examples from Mountainous Adygeja (Russia). Geološki anali Balkanskoga poluostrva 76, 93-104.

Goehring, L. \& Morris, S.W., 2008. Scaling of columnar joints in basalt. Journal of Geophysical Research: Solid Earth 113, B10203.

Gray, M., 2013. Geodiversity: valuing and conserving abiotic nature. Wiley-Blackwell, Chichester, $495 \mathrm{pp}$.

Habibi, T. \& Ruban, D.A., 2017. The Oligocene carbonate platform of the Zagros Basin, SW Iran: An assessment of highly-complex geological heritage. Journal of African Earth Sciences 129, 675-682.

Haghe, J.-P., 2011. Do waterfalls have value in themselves? A metamorphosis in the values of the Gimel waterfall in France. Policy and Society 30, 249-256.

Hofmann, M., Anderssohn, R., Bahr, H.-A., Wei $\beta$, H.-J. \& Nellesen, J., 2015. Why Hexagonal Basalt Columns? Physical Review Letters 115, 154-301.

Hose, T.A., 2000. European 'geotourism' - geological interpretation and conservation promotion for tourists. [In:] D. Barettino, W.A.P Wimbledon \& E. Gallego 
(Eds), Geological heritage: its conservation and management. ITGE, Madrid, 127-146.

Hose, T.A., 2012. 3G's for modern geotourism. Geoheritage $4,7-24$.

Hose, T.A., 2016. Three centuries (1670-1970) of appreciating physical landscapes. Geological Society Special Publication 417, 1-22.

Hudson, B.J., 2002. Best after rain: Waterfall discharge and the tourist experience. Tourism Geographies 4, 440-456.

Hudson, B.J., 2013. Waterfalls, science and aesthetics. Journal of Cultural Geography 30, 356-379.

Jorgenson, J. \& Nickerson, N., 2016. Geotourism and sustainability as a business mindset. Journal of Hospitality Marketing and Management 25, 270-290.

Kantha, L.H., 1981. 'Basalt fingers' - origin of columnar joints? Geological Magazine 118, 251-264.

Kirillova, K., Fu, X., Lehto, X. \& Cai, L., 2014. What makes a destination beautiful? Dimensions of tourist aesthetic judgment. Tourism Management 42, 282-293.

Lubova, K.A., Zayats, P.P., Ruban, D.A. \& Tiess, G., 2013. Megaclasts in geoconservation: sedimentological questions, anthropogenic influence, and geotourism potential. Geologos 19, 321-335.

Moroni, A., Gnezdilova, V.V. \& Ruban, D.A., 2015. Geological heritage in archaeological sites: case examples from Italy and Russia. Proceedings of the Geologists' Association 126, 244-251.

Necheş, I.-M. \& Erdeli, G., 2015. Geolandscapes and geotourism: integrating nature and culture in the Bucegi Mountains of Romania. Landscape Research 40, 486509.

Peacock, D.C.P., Nixon, C.W., Rotevatn, A., Sanderson, D.J. \& Zuluaga, L.F., 2016. Glossary of fault and other fracture networks. Journal of Structural Geology 92, 12-29.

Phuong, T.H., Cu, N.H., Thanh, T.D. \& Van Dong, B., 2013. Geoheritage values in the Cat Ba islands, Vietnam. Environmental Earth Sciences 70, 543-548.

Plumb, G.A., 1993. A scale for comparing the visual magnitude of waterfalls. Earth-Science Reviews 34, 261-270.

Plyusnina, E.E., Ruban, D.A. \& Zayats, P.P., 2015. Thematic dimension of geological heritage: an evidence from the Western Caucasus. Journal of the Geographical Institute "Jovan Cvijic" SASA 65, 59-76.

Ruban, D.A., 2010. Quantification and geodiversity and its loss. Proceedings of the Geologists' Association 121, 326-333.

Ruban, D.A., 2015. Geotourism - A geographical review of the literature. Tourism Management Perspectives 15, $1-15$.

Suttner, T.J., Kido, E., Königshof P., Waters, J.A., Davis, L. \& Messner, F. (Eds), 2016. Planet Earth - In Deep Time.
Palaeozoic Series. Devonian and Carboniferous. Schweizerbart Science Publishers, Stuttgart, $261 \mathrm{pp}$.

Tourtellot, J.B., 2006. Geotourism for your community A guide for a geotourism strategy. Centre for Sustainable Destinations, National Geographic Society, Washington, $24 \mathrm{pp}$.

Tucker, M.E., 2011. Sedimentary rocks in the field. A practical guide. Wiley-Blackwell, Chichester, $276 \mathrm{pp}$.

Unjah, T., Leman, M.S. \& Komoo, I., 2013. Geological landscape and public perception: A case for Dataran Lang viewpoint, Langkawi. Bulletin of the Geological Society of Malaysia 59, 101-107.

van der Jagt, A.P.N., Craig, T., Anable, J., Brewer, M.J. \& Pearson, D.G., 2014. Unearthing the picturesque: The validity of the preference matrix as a measure of landscape aesthetics. Landscape and Urban Planning 124, 1-13.

Veress, M., 2016. Covered karsts. Springer, Dordrecht, 536 pp.

Veress, M., Zentai, Z., Péntek, K., Mitre, Z., Deák, G. \& Samu, S., 2013. Flow dynamics and shape of rinnenkarren systems. Geomorphology 198, 115-127.

Veress, M., Zentai, Z., Pentek, K., Dobrontei, L. \& Kiprijanova, L.D., 2014. The development of the pinnacles (Lena pillars) along Middle Lena (Sakha Republic, Siberia, Russia). Proceedings of the Geologists' Association $125,452-462$.

Walliss, J. \& Kok, K., 2014. New interpretative strategies for geotourism: an exploration of two Australian mining sites. Journal of Tourism and Cultural Change 12, 33-49.

Wang, S., Wang, J.H.-H., Chen, Y.-T. \& Sheu, L.-Y., 2005. Promoting Penghu Geopark. [In:] The Penghu Vision: An International Conference to Explore Geological and Geomorphological Conservation in a Taiwan Context. Penghu County Government, Magong City, 109-134.

Wang, L., Tian, M. \& Wang, L., 2015. Geodiversity, geoconservation and geotourism in Hong Kong Global Geopark of China. Proceedings of the Geologists' Association 126, 426-437.

Warowna, J, Zglobicki, W., Kolodynska-Gawrysiak, R., Gajek, G., Gawrysiak, L. \& Telecka, M., 2016. Geotourist values of loess geoheritage within the planned Geopark Malopolska Vistula River Gap, E Poland. Quaternary International 399, 46-57.

Weaire, D. \& O'Carroll, C., 1983. A new model for the Giant's Causeway. Nature 302, 240-241.

Woo, S.K., Sohn, Y.K., Ahn, U.S., Yoon, S.H. \& Spate, A., 2013. Jeju Island Geopark - A volcanic wonder of Korea. Springer, Berlin, 88 pp.

Manuscript received: 21 July 2016 Revision accepted: 28 February 2017 